\title{
Prehistoric Grinding Tools as Metaphorical Traces of the Past
}

\author{
Cecilia Lidström Holmberg
}

\begin{abstract}
The predominant interpretation of reciprocating grinding tools is generally couched in terms of low archaeological value, anonymity, simplicity, functionality and daily life of women. It is argued that biased opinions and a low form-variability have conspired to deny grinding tools all but superficial attention.
\end{abstract}

Saddle-shaped grinding tools appear in the archaeological record in middle Sweden at the time of the Mesolithic - Neolithic transition. It is argued that Neolithic grinding tools are products of intentional design. Deliberate depositions in various ritual contexts reinforce the idea of grinding tools as prehistoric metaphors, with functional and symbolic meanings interlinked.

Cecilia Lidström Holmberg, Department of Archaeology and Ancient History, S:t Eriks torg 5, Uppsala University, SE-753 lO Uppsala, Sweden.

\section{THE OBSERVABLE, BUT INVISIBLE} GRINDING TOOLS

Grinding tools of stone are common archaeological finds at nearly every prehistoric site. The presence and recognition of these artefacts have a long tradition within archaeology (e.g. Bennet \& Elton 1898; Hermelin 1912:6771; Müller 1907:137,141; Rydbeck 1912:8687). It is appropriate to acknowledge that previous generations of archaeologists to some extent have raised questions related to the meaning and role of grinding tools, including associated activities (e.g. Rydbeck 1912:86). It is obvious, however, that these ideas have not been further developed within the archaeological discipline. Prehistoric remains of domestic daily life have been acknowledged since the beginning of archaeology, but have had low priority and status compared with other subjects of archaeological research. Although grinding tools are found in abundance, they are seldom actively used in interpreting the past. Many grinding tools have probably not even been recognised as tools. The handling of grinding and pounding tools found during excavations depends on the excavation policy, or rather on the excavators' sphere of interest (see e.g. Kaliff 1997).

As grinding tools of stone often are bulky and heavy objects, they are rarely retained in large numbers (Hersch 1981:608). By tradition, reciprocating grinding tools are archaeologically understood and treated as an anonymous category of objects. They are therefore often neglected in archaeological publications (Lidström Holmberg 1993). The predominant interpretation of these tools is usually couched in terms of functionality, simplicity, and daily life of women (Last 1996). A traditional bias and low form-variability have probably conspired to deny reciprocating grinding tools all but superficial consideration.

The perceived anonymity has implications for description, typology and terminology, as 
well as for deeper interpretation and the production of knowledge. One reason for the lack of close attention is the fact that grinding tools are rarely considered to have important archaeological value. Their low status is most probably linked to the overall interpretation of grinding tools as purely functional domestic objects. It is consequently assumed that they have no social intentional meanings beyond the functional, and are not socially valueladen. The most important reason for the lack of attention is very likely the fact that interesting archaeological questions have not been integrated with these "ordinary" domestic artefacts.

As reciprocating grinding tools are thought of as both anonymous and non-valuable, they simultaneously seem to fall out of the sphere of what is archaeologically worth knowing. In this article I would therefore like to draw attention to the archaeological qualitites of grinding tools in general, and Neolithic grinding tools in particular. My intention is to show that Neolithic grinding tools were objects beyond the practical, with the functional and symbolic meanings closely interlinked. I further argue that the grinding tool may be interpreted as an active part of the Neolithic social and ritual life. The wider social perspective of these "forgotten" archaeological artefacts is the vital key to my interest in prehistoric grinding tools.

\section{Theoretical framework}

The remains of the past are observable as traces. No one can question the fact that a prehistory, or rather several prehistories, once existed. The archaeological knowledge is, however, created through observation and interpretation of visible traces within a present. When trying to interpret these traces, you invariably become involved in a dialogue between the remains of the past and the understood present. This dialogue may be called a discourse. The word "discourse" derives from the Latin discurrere, meaning "to run back and forth" (Lübcke 1988:117). The discourse concept has been used and understood in multiple ways. In this discussion it refers to how an object, phenomenon or a chain of statements receives meaning within a fixed framework of acceptance (Lübcke 1988:117). Our observations of prehistoric remains are created within the conceptual framework that is active in the present. The observation is in itself therefore value-laden, as both observations and interpretations are made through our previous knowledge, current values, prejudices and expectations (Damm 1991:23-25).

The conceptual framework is partly formed through ideas of what is accepted or traditionally held knowledge. This may be interpreted as what is archaeologically "seeable and knowable" within current discourse. It is argued that this relationship also affects grinding tool interpretations.

The fact that the remains of the past are found, observed and interpreted within a present conceptual framework is determinant for the production of archaeological knowledge. It is, however, of ultimate importance to recognise that theory and data depend on each other, as "in practice the levels of interaction with both theory and data, and between the two, can not be separated"' (Sørensen 1988: 14). Both the revision and creation of archaeological knowledge are therefore answerable to two sets of constraints: plausibility considerations and empirical constraints (Wylie 1982: 42).

\section{Grinding tool typology}

When stone artefacts are observed and documented during fieldwork, a general classification system as well as questions of categorising and labelling often creates practical problems (Ballin 1996:3). A general method of archaeological classification is to make detailed descriptions of morphology, material and dimensions. During my studies of Neolithic stone tools used for pounding and grinding (Lidström Holmberg 1993), I entered into a haphazard classification and a random terminology. Artefacts showing use-wear from pounding, grinding and polishing are usually given cursory attention, and are often classified as "other artefacts" (e.g. Ballin 
1996:62). Within this "other artefact" category, grinding tools are given a multitude of labels (Petré 1984). Grinding tool labels are, however, seldom related to actual morphology, tool design or use-wear modification. The terminology consequently becomes extremely confusing. The distinction between handstones and grinding slabs is, for example, frequently neglected, as are general descriptions of morphology (Lidström Holmberg 1993:12-13; Kraybill 1977:485-486). This neglegence of prehistoric grinding-tool typology is in sharp contrast to my archaeological experiences of grinding tools as deliberately designed as well as symbolically used objects. Especially the distinction between the handstone and the grinding slab should be considered important, as ethnograhical information suggests an active symbolic relationship between the two parts (Corbeil 1985; Parsons 1970). In this article I have chosen the term "grinding slab" when describing the lower part of a grinding-tool set, and "handstone" when discussing the upper part (see Kraybill 1977:487).

The terminology connected with grinding tool types is obviously problematic. The lower, or stationary, part of the grinding-tool set may be labelled as grain-rubber, quern, grindstone, grinding stone, mealing stone, grinding dish, saddle-quern, milling stone, metate or flat mill. The upper, mobile part of the tool set may be labelled as rubber, muller, handstone, grinder, mealing stone, rider, hand millstone, mano or milling stone (Carter 1977; Kraybill 1977). In The Domestication of Europe (Hodder 1990), grinding-tool labels are as confusing as ever. Millstones, mills, grinders, stone querns, grindstones, saddlequerns and grinding stones are discussed without further discussion of tool morphology (Hodder 1990: e.g. 33, 51, $57,66,123)$. The suggestion made by George Carter (1977) to adopt a general terminology for the distinction between metate (lower part of the grinding-tool set) and mano (upper part), seems to have been actively accepted and found useful within current American archaeology.
To produce complex knowledge about the prehistoric past, archaeological research must define and redefine its data. One important aim included in this process of redefinition must be to question the conventional labels of artefacts. The label in itself may carry important meaning, with implications for archaeological interpretation and understanding. One expression of this is the way grinding tools usually are described as grinding "stones" instead of grinding "tools". The designation of the word "grinding stone" presupposes an artefact form created through use alone. The word does not suggest any technological choices, technological decision-making, or social intentions other than using any two stones together. The designation of the word "tool" is rather different. It implies an initial artefact form that is "actively" manufactured to be effective for a specific task (Nelson \& Lippmeier 1993:286). A "tool" is a product of careful, initial and intentional design, a "stone" is normally not. The basic problem connected with revaluing grinding tools is that the grinding-tool shape is thought of as "directly related to its use" (Kraybill 1977:487). This has implications for the archaeological value, as a valued object normally is related to the degree of intentionality associated with the object.

A first step towards a methodology of grinding tools is to develop a critical terminology according to technical morphological traits and use-wear modification. Careful analysis of grinding-tool form often explores initial grinding-tool design, although the tool form obviously develops during its life-time as use modification alters its nature (Lidström Holmberg 1993:12; Nelson \& Lippmeier 1993). In spite of the superficial and homogeneous appearance, grinding tools can be valued as products of social and technological decisionmaking.

American archaeologists have a tradition of analysing and interpreting grinding-tool design, especially in questions related to tool function (Adams 1988), but also in relation to site variability, sedentism, population density, 
tool manufacturing, social organisation, and change in subsistence (Hard, Mauldin \& Raymond 1996; Nelson \& Lippmeier 1993; Stone 1994; Wright 1991). Nelson \& Lippmeier (1993) shows a correlation between the regularity of site occupation and handstone morphology. Stone (1994) suggests that access to raw materials for grinding-tool manufacture probably affects handstone size. Hard, Mauldin \& Raymond (1996) uses Bolivian ethnoarchaeological data in demonstrating that measurements of handstone size are related to grinding capacity, and may provide a measure of different levels of agricultural dependence. Ethnographic information also indicates that handstone shape is related to subsistence (Thompson 1964:407).

Frank Hole (1977) has paid extensive consideration to grinding-tool types in relation to chronology. An abundance of grinding and pounding tools were found within various early agricultural settlements excavated in the Deh Luran plain in south-west Asia. The results showed that grinding tools are as characteristic of chronological phases as ceramics and other artefacts (Hole et al. 1977:200-208).
Although American archaeologists have indeed raised questions about grinding-tool use, and tool typology, they generally do it in a traditional American way. The explanations and interpretations are consequently often based upon questions related to function and subsistence. However useful these explanations may be, they do not give an understanding of grinding tools as socially active objects.

\section{Negative conceptual framework}

The traditional bias against a wider interpretation of reciprocating grinding tools may in part be related to their apparent low level of form-variability and minimal stylistic information in grinding-tool form (Hard, Mauldin \& Raymond 1996:254; Hersch 1981:2). I also propose that the low archaeological value associated with grinding tools is partly due to the fact that they are interlinked with a set of historical values (fig. 1). These reproduced and often rather negative associations are subsequently brought into the archaeological understanding of today.

During the Late Iron Age the hand-driven grinding tools were often replaced by mechanised water-mills (Schön 1995:113). During

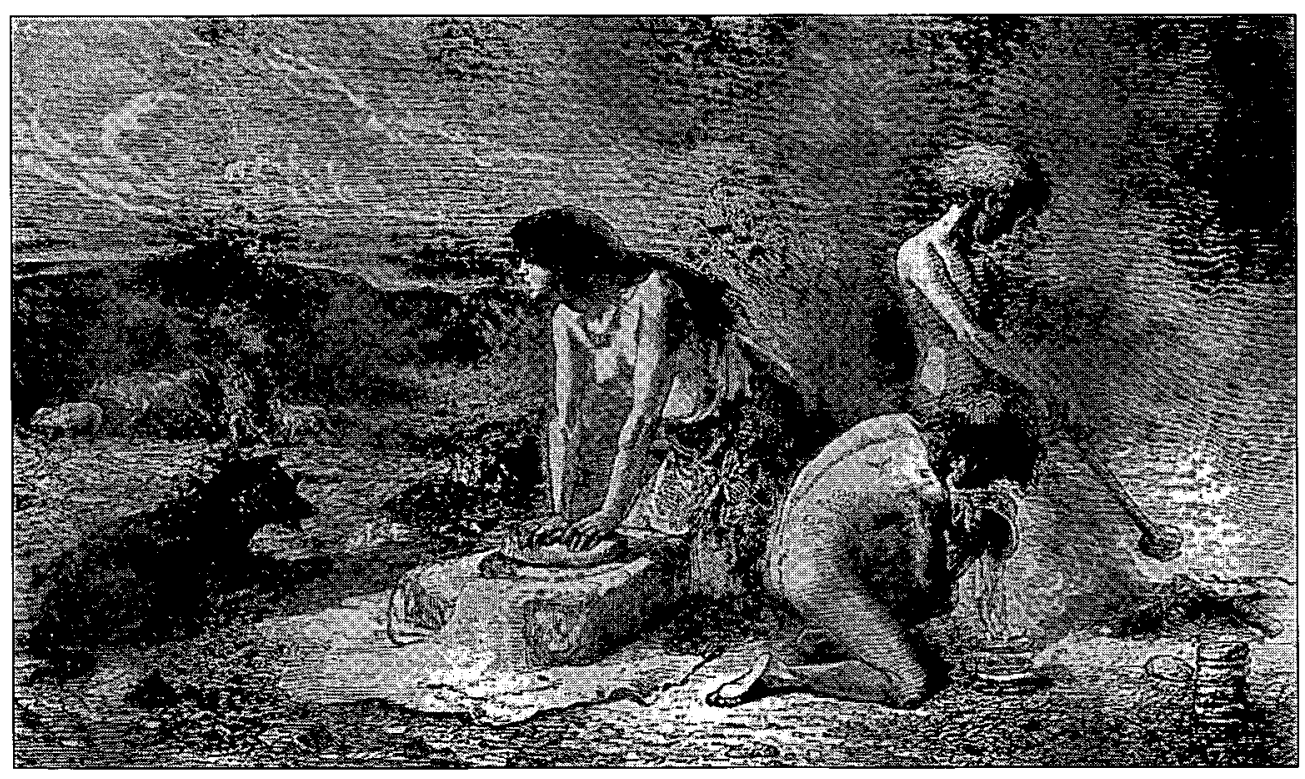

Fig. 1. An evolutionary perspective of "The art of bread making in the Stone Age". Illustration by Figuier in Primitive Man (1876). After Barker 1985:fig. 3. 
the Middle Ages the activity of grinding was rapidly transformed into a water- and windmilling industry owned by men with power. Feudal norms and laws regulating the milling were brought in from the Continent. Peasants and other subordinate groups were forced by law to only grind at mills owned by the landowners. They were not allowed to use other water-mills or privately owned hand grinding tools (Bennet \& Elton 1898:210; Ek 1981: 544). Grinding by hand was considered a hard and monotonous duty performed by uneducated poor people, women and slaves. Special treadmills were even used as a humiliating penalty for unruly male prisoners in some English 19th-century prisons (Bennet \& Elton 1898:228; Fendin 1994:11-12). The reproduced picture of grinding as representing hard labour, as well as a monotonous and unqualified female task, is part of our present conceptual framework.

A negative historical reproduction should not prevent new and unexpected experiences, or new "positive" reinterpretations of grinding tools as objects with multiple meanings. To be able to use grinding tools as value-laden objects, the conventional assumptions must be challenged. Included in this challenge is an engendering of archaeological interpretations of the past (Dobres 1995; Gero \& Conkey 1991).

\section{HUMAN AGENCY - GRINDING TOOLS AS GENDERED METAPHORS}

An engendered archaeology aims at studying social dynamics with a critical use of gender theory (Conkey 1993). Anna-Marcia Dobres (1995a) means that this requires a development of gender theory within archaeology itself, and above all conceptual changes in method. An engendered archaeology is therefore not synonymous with an archaeology of gender. To engender the past also demands critical rethinking of how knowledge is produced within the archaeological discourse.

Dobres' conclusions about gender in archaeology and an engendered archaeology bring us to the point where we can discuss gendered activities and material culture in a wider perspective than "who did what" in prehistory. The most important point made by Dobres is her understanding of gender systems as institutionalised systems of underlying values within societies. "...To engender the past is also to ask about prehistoric value systems as expressed in and negotiated through quotidian activities that leave behind material traces" (Dobres 1995a:53).

Questions such as, "what about the past is knowable, and what is worth knowing" (Dobres 1995a:53), are important factors when discussing an engendered archaeology. They are of equal importance when discussing grinding tools as valuable data. I propose a critical analysis of what is "knowable and worth knowing". Not only must we open our eyes to this "new" category of artefacts, but we also have to rethink the categories through which this archaeological record is interpreted (Roberts 1993:17). It is interesting to note that critique of underlying disciplinary assumptions does not always accompany observations of new archaeological data (Roberts 1993:18). The ordinary interpretation of prehistoric grinding tools is still in terms of function and subsistence, but is often dismissed within current archaeological discourse. A rethinking as well as a revaluing of these "ordinary, natural and bulky" tools must therefore involve critical theory, changes in attitudes, as well as asking basic critical questions about both old and new data.

Grinding tools are, according to ethnographic descriptions, the only stone tools that are directly linked to female activities, from tool manufacturing, maintenance, to food preparation (Haaland 1997:379). Grinding tools were sometimes used by men (Bird 1993), but only for specific activities such as the grinding of tobacco or ochre (Haaland 1997:379). Women are also regularly associated with hearths, cooking pots, and the processing of food. In addition they have been associated with deposited refuse from cooking, hearth ash, and food rubbish (Bird 1993; Hastorf 1991; Moore 1986). 


\section{Neolithic grinding tools}

Some archaeologists have presumed that a change in gender relations took place during the Neolithic period (Hastorf 1991). This is a question worth discussing, as I am going to argue that there seems to be a change in grinding-tool design as well as grinding-tool use from the Mesolithic to the Neolithic. If an economic and social organisation of gender relations structured the Neolithic life, it may also be observable in the daily material culture associated with grinding tools and food processing techniques. Studies of intrasite spatial distribution of artefacts show that grinding tools may be used in interpretations of social structuring. Separate areas for axe production and areas with grinding equipment and other food processing remains have been observed within Early Neolithic settlement sites (see e.g. Apel (Ed). in press; Hallgren et al. in press 1997). The archaeological patterning may be recognised as having been formed through a general structure of values and ideas in which gender is a structuring principle (see Moore 1991:407).

An analysis of two Linear Bandkeramik (LBK) cemeteries in northern Europe, Elsloo in the Netherlands and Niedermerz just across the border to Germany, has shown that Neolithic grinding tools may be seen as gender specific (Van de Velde 1992). Van de Velde defines gender as a sexual division of labour, in pure economic terms. This gender division is proposed to be expressed in the burials within the LBK culture, visible as two separate tool kits (Van de Velde 1992:176). Grinding tools, red ochre and flat adzes are by Van de Velde interpreted as a female expression, whereas thick adzes, blades and arrowheads represent a male expression (Van de Velde 1992:176). These gendered graves also show a geographical patterning, as graves of opposite gender seem to have been placed closer to each other than graves of the same gender. This structure of pair bonding is suggested to reflect the Bandkeramik division of labour. In addition, in post-LBK graves in Hinkelstein in the Rheinland, female graves are linked with grinding tools, pottery ornaments, and light stone tools. In Aiterhofen in Bavaria female graves contain grinding tools, awls, and ornaments (Hodder 1990:110).

As grinding tools overall are possible to interpret as gendered metaphors, they are also relevant in discussing gender relations within early farming communities. Interpreting grinding tools as metaphorical traces must, however, involve critical gender theory to aim for an engendered archaeology. The relationship between the archaeologically observable technical attributes and the wider social technological framework is crucial to this aim (see Dobres 1995b). By studying the technical attributes involved in the design of grinding tools e.g. morphology, function, use-modification and associated activities it is possible to reach into the wider and less tangible social values which may have structured or influenced tool design and tool use. Central analytical categories related to a social technology of grinding tools are gender structures, ideology and human intentionality.

\section{INTENTIONAL INVESTMENT IN} NEOLITHIC GRINDING-TOOL DESIGN

Grinding tools of various sizes and models existed already during the Mesolithic period in middle Sweden (Risberg et al. ms; Welinder 1977:28). The Mesolithic grinding tools are usually smaller and less standardised in form than the Neolithic grinding tools. The Mesolithic grinding-tool set is usually made up of a one-handed handstone, used in circular and pounding motions on a variety of grinding slabs or other surfaces. These tools were most probably multi-task-functional tools, used for grinding and pounding nuts, wild plants and tubers for food and medicinal purposes, or grinding ochre for paint (Kraybill 1977). Some one-handed handstones with shiny use-wear traces on the working surfaces may also have been used for one or more hide-processing tasks as suggested by use-wear analyses conducted by Jenny Adams (1988). Hunter/gatherer grinding-tool design remained static on several continents for millennia. Hard, Maul- 
din \& Raymond (1996:257) suggests the functional explanation that the added energetic costs related to manipulating a larger stone might have been thought of as impractical for the crushing of wild seeds.

It is not until the Mesolithic - Neolithic transition that large, actively designed grinding tools appear in the archaeological record in middle Sweden (Florin 1958; Hallgren 1996:9; Kihlstedt 1996:75). A saddle-shaped grinding slab and a two-handed, loaf-shaped handstone make up the characteristic Early Neolithic grinding-tool set. Tools of this particular type are known from several Early and Middle Neolithic sites in middle Sweden (Kihlstedt 1996:74-75; Hallgren et al. 1995b; Olsson 1996:46; Lidström Holmberg 1993).

Earlier archaeologists did not agree upon the distinction between grinding tools and polishing tools used for, among other things, stone and flint artefacts. Axel Bagge classified the distinct and loaf-shaped artefacts as polishing stones (Florin 1958:28). The concept "loaf-shaped grinding stone" was first used by

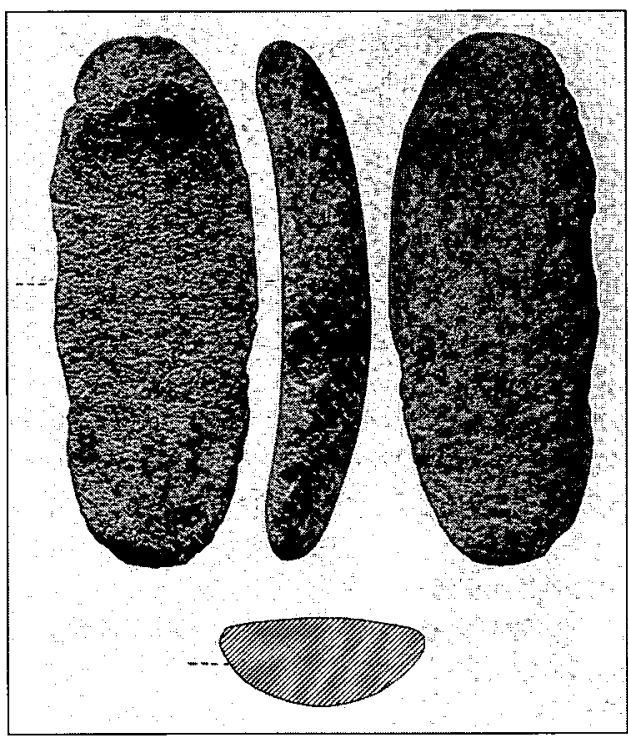

Fig. 2. An intact, loaf-shaped handstone from the Early Neolithic site of Brokvarn. Turinge parish in Södermanland. The handstone, made of arcosic sandstone, is elaborately produced by knapping and pecking. Handstone length $31 \mathrm{~cm}$. After Florin 1958:PI. XXVII.
Sten Florin (1958:129), who maintained that this artefact was in fact a grinding slab (fig. 2). Small, rounded, one-handed tools made of granite, porfyrite or sandstone belonged to the tool kit, and were said to have been used as handstones (Florin 1958:191). This is the present, traditional way of reconstructing this typical grinding-tool set.

Experimental grinding on replicated grinding-tool copies shows that small rounded handstones could not have created the usewear pattern of the saddle-shaped grinding slabs. Analyses of the interaction of grinding surfaces, with special attention paid to friction and lubrication, show that Florin's grinding slab has been used as a two-handed handstone. Analyses of use-wear traces on the same types of Neolithic grinding tools clearly reinforce the results from the experimental studies. The use-wear studies clearly indicate that a loafshaped handstone belongs to a saddle-shaped grinding slab. In addition, a handstone of the loaf-shaped type seems to have been manufactured for use on one particular slab only (Lidström Holmberg 1993).

A complete grinding tool of the saddleshaped type was found in situ during an excavation of the Kyrktorp site, Grödinge parish, in eastern Södermanland (Olsson 1992, 1996:46; Lidström Holmberg 1993:22-24). The site yielded finds from the Mesolithic, Middle Neolithic and Early Iron Age. The finds from the Middle Neolithic covered a large area and are classified as belonging to the Pitted Ware Culture. During the Middle Neolithic the excavated part, a steep slope at 25-35 m.a.s.l, was situated close to the ancient Litorina seashore (Risberg et al. $\mathrm{ms}$ ). The grinding-tool set had been carefully placed in the steepest part of the slope. The intact and fully functional saddle-shaped grinding slab was found with the loaf-shaped handstone lying on top of it (fig. 3). Both parts are carefully designed by knapping, pecking and grinding. It is interesting to note that the tool set seems to have been deliberately deposited at this particular place.

Since reciprocating grinding tools often 


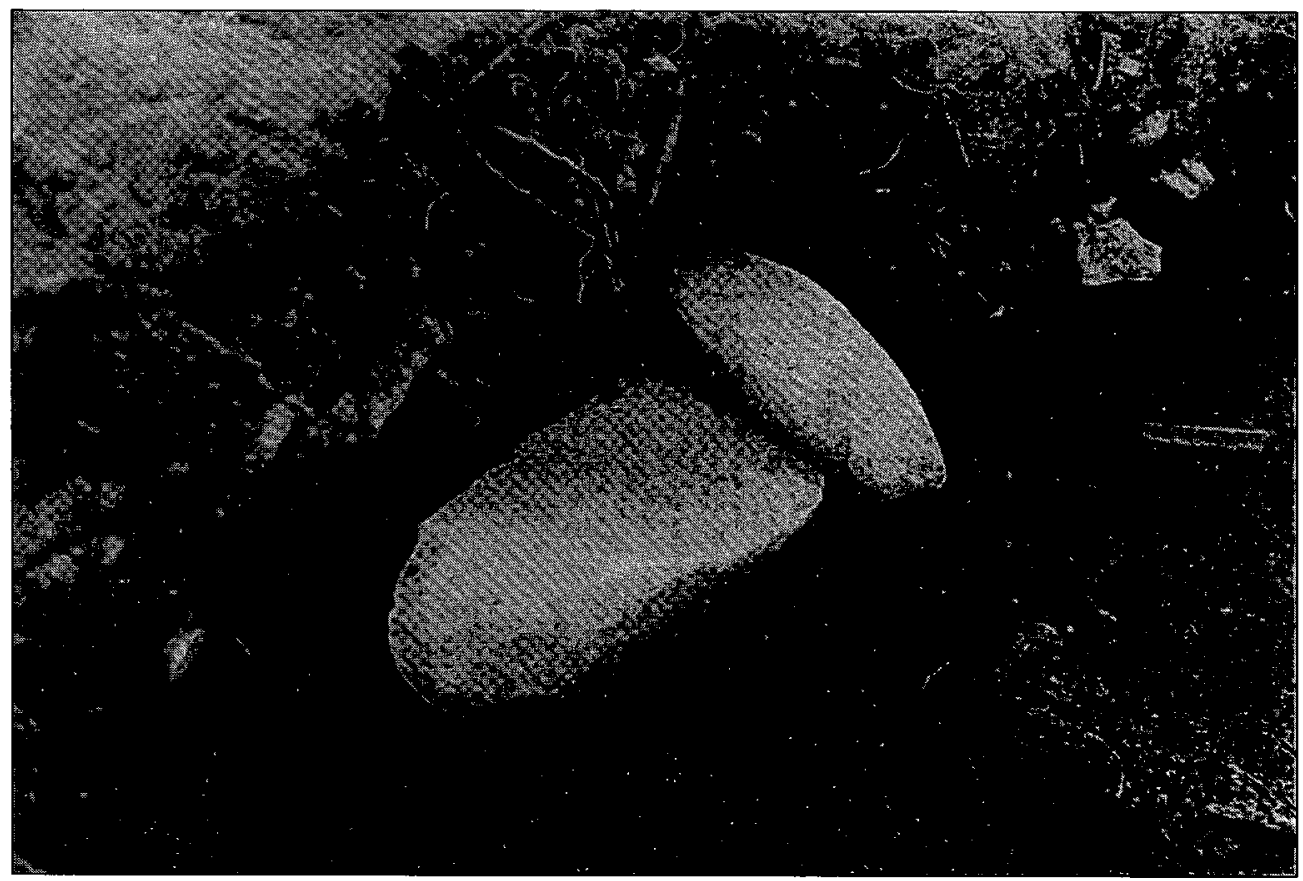

Fig. 3. A saddle-shaped grinding slab with its elongated, loaf-shaped handstone lying on top. A unique in situ find during the excavation of the Kyrktorp site, Grödinge parish, in Södermanland. Both tool parts are made of arcosic sandstone. Photo: $M$. Fristedt.

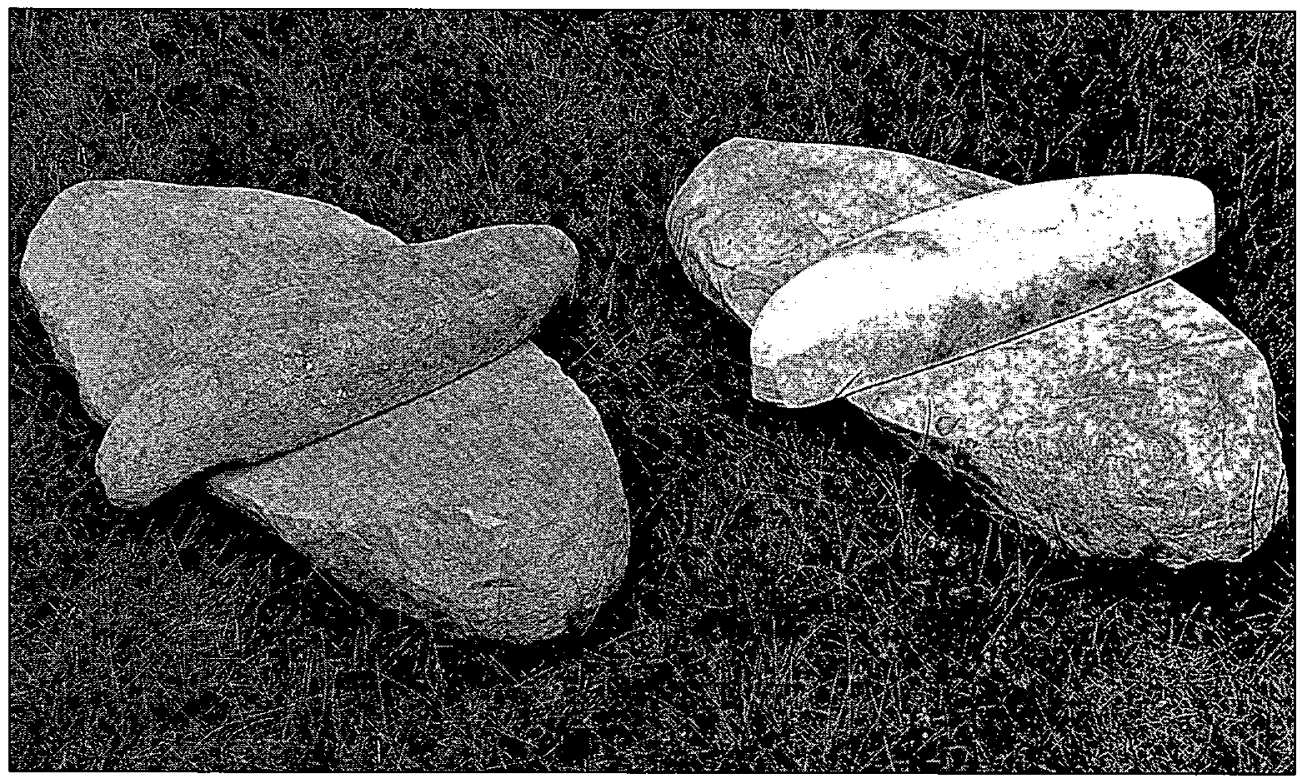

Fig. 4. The complete grinding-tool set from the Kyrktorp site (left), and its replicated copy (right). Original handstone length $35 \mathrm{~cm}$, and grinding slab length $56 \mathrm{~cm}$. Note the elaborately pecked handstone back and the characteristic use-wear modification, e.g. beak-shaped handstone ends and a slighly convex crosssection of the grinding slab. Photo: Ulf Bruxe. 
are perceived as morphologically similar, it is important to establish some "morphological rules" regarding the relationship of artefactdesign to the observer (Lidström Holmberg 1993:40-44). Knapping and pecking usually elaborately produce both the saddle-shaped slab and the loaf-shaped handstone. The process is sometimes complemented by grinding.

The term saddle-shaped grinding slab refers to the upper surface of the implement, which resembles a saddle (fig. 4). The long axis is concave, but the cross-section is more or less convex. The sides of the saddle-shaped slab are usually carefully pecked into shape. The back of the slab, that is the side resting on the ground, is sometimes pecked into a rounded form, but is usually left without further manufacturing. The slab is often twice as long as it is wide. Its grinding surface is not surrounded by ridges along the long axis. This morphological trait is determined by use-wear, as the elongated handstone has been ground over the long sides of the slab. The lack of ridges distinguishes saddle-shaped slabs from so-called trough-formed grinding slabs. The latter were used with smaller, discoidal or rounded handstones (fig. 5). Use-wear friction caused by a smaller handstone creates a different use-modification with ridges all around the slab, as the handstone's length is shorter than the grinding slab is wide.

As the name implies, the loaf-shaped handstone has a plano-convex form clearly resembling a loaf of bread. Normally, a loaf-shaped handstone is worn on one side only. This is a clear indication that the grinding motion was back and forth without a shift in the handstone position. The convex, carefully pecked back of the handstone is left unused, and the initial design is therefore not altered by friction. It often displays micromorphological phenomena such as gloss, emanating from the hands of the prehistoric user (Bauche 1986:55). The handstone is normally longer than the saddleshaped slab is wide, resulting in more pressure and wear at the two ends of the handstone's long axis. Over time the friction promotes beak-shaped handstone ends. The same motion also gives the surface of the grinding slab a more or less convex cross-section (Adams 1988:310-312; Lidström Holmberg 1993:41).

Shaping and standardisation in form suggest an intentional investment in grindingtool design. Conceptions of how a modern Neolithic grinding-tool set should look like, must have have been acknowledged by Neolithic grinding-tool producers. The similarity in design may for example, be a result of a wish for tool effectivity, as there is a strong relationship between grinding capacity and the length of the grinding slab. For a given particle density and grinding time, capacity is said to increase as a cubic function of grinding surface length (Hard, Mauldin \& Raymond 1996:256). Grinding capacity is, however, also related to other variables such as the soaking or roasting of cereals before grinding, ground particle size, grinding skills, grinding motions, and the need for re-pecking of the grinding surface (Lidström Holmberg 1993; Wright 1990).

The "stone-sliding-against-stone" contact between the handstone and the slab promote over time a typical flat and smooth grinding

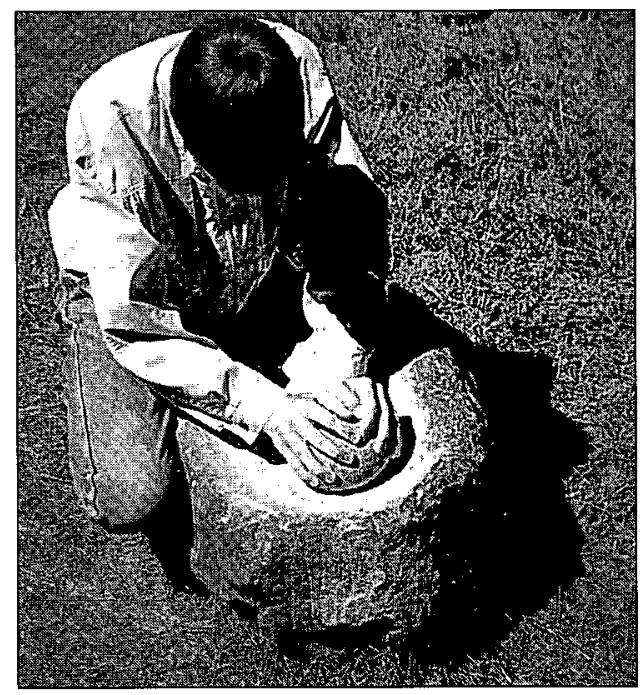

Fig. 5. A trough-formed grinding tool. A small, rounded handstone has created high ridges all around the slab. Photo: $C$. de Lange. 
surface. A smooth surface is not suitable for effective grinding. To increase grinding capacity the surface must be re-roughened. Re-pecking the surface with a hard hammerstone accomplishes this. Different stages of worn-flat and re-pecked grinding slab surfaces have been observed both in the archaeological record and the ethnographical record. Repecking was obviously an important practice used within prehistoric grinding-tool technology. Some of the one-handed pounding stones with pronounced facets, frequently found within prehistoric sites, may be associated with this practice (see Jørgensen Bloch 1991).

Nancy Kraybill (1977:490) describes how hammerstones of good quality were considered important items of trade among African women. The hammerstones were selected with care, and were valuable objects owned by women. All grinding tools were re-pecked by the women themselves. Grinding tools used among nomads living in eastern parts of the Sahara were made of hard sandstone. Smooth, worn-out, grinding surfaces were repeatedly pecked by the women every week, to render the tools effective again (Schön \& Holter 1988:157, 159). The grinding slab lasted for about five or six years. The handstones were rather small and lasted for about one or two years.

It is important to consider that the production of Neolithic grinding tools most probably required considerable technological knowledge, and was part of a social production. In her doctoral dissertation, Hersch concludes that the manufacture of grinding tools in $\mathrm{Ne}$ olithic Turkey was a multi-stage process. It required full understanding of the material being used, as well as knowledge of manufacturing techniques and tools available for the procurement of raw material (Hersch 1981: 602). Some ethnographic information indicates that the most effective and high-quality grinding tools were considered valuable objects, and were passed down as heirlooms to the next generations (Sharovskaja 1992:51).

Little is, however, known about the manufacture of prehistoric grinding tools, or grinding tool technology in general. As grinding tools are part of prehistoric technology, they must be valued as intentionally manufactured tools within a cultural framework. This has implications for using grinding tools as meaningful information, as "artefacts are produced and used in a context of interacting people, and thus have meaning in a social context of symbols and ideas" (Haaland 1995:164).

\section{SHARED IDENTITY, SHARED METAPHORS}

Whittle (1996:70) has defined the concept of community as being created "through shared outlook and shared concepts of classifying and valuing, as well as shared activities including shared expectations and obligations". The morphological changes in grinding-tool design that appear in the archaeological record in the Mesolithic - Neolithic transition, are suggested to be linked to dynamic changes within these communities. Ethnographical information, as well as the social production related to grinding-tool design and grindingtool use, strongly suggests that these tools are not simply functional in the strict sense. Shared ideas of grinding tools as social and ritual metaphors are proposed to be included within the conceptual domestication of Neolithic communities. The grinding tool may, in the words of Julian Thomas, be seen "as a thing to think with" (Thomas 1991:184).

What object is to be considered symbolic depends on the amount of intentionality associated with the object. The causal connection between intentions and symbolism seems to offer resistance to the interpretation of grinding tools as prehistoric metaphors. The distinction often made between functional-domestic and non-functional - ritual is unfortunate, as "ritual is a form of human action which may involve a range of forms of material culture, from the most mundane to the most explicitly symbolic" (Thomas 1996:8).

The definition of symbolism as active in all parts of a society, including daily life, is of the utmost importance (Engelstad 1991; 
Hugh-Jones 1996:193). Archaeological research on symbolism has mainly been connected with specific parts defined by the archaeological discourse as symbolic spheres of a society. Objects that can be separated from the sphere of daily life are subsequently distinguished as symbolic objects. The fact that symbolism is interpreted as an epiphenomenon excluded from every day life is problematic (Engelstad 1991:24) and affects the interpretation of domestic objects. The symbolic significance of an object, such as the grinding tool, is a question of cultural associations. The object may represent internal experiences of culturally defined values and concepts recognised by members of a group or a society. To understand the symbol actively in terms of original ideas, it must be "read" by people with a similar world of experiences, sharing a similar set of cultural values (Lidström Holmberg 1993). When it comes to discussing prehistoric symbolic messages, we must therefore try to define the context of the communal experiences in which the symbol was active. The concepts must give meaning to the experiences of the object towards which the experience is directed. As the past is forever lost, we are forced to create alternative experiences in bringing prehistoric metaphors to active life.

\section{ALTERNATIVE EXPERIENCE - THE ETHNOGRAPHIC RECORD}

To create a wider platform for interpretation, it is important to create alternative experiences for the relationship among people, things, and social value-systems. I started to search for literature on the utilisation of grinding tools in general, for historical accounts as well as observations and descriptions by anthropologists. The information is not thought of as evidence or proof of the relationship between prehistoric contexts and objects, but rather "as sources to reflect what these contexts might have been" (Haaland 1995:164).

The ethnographic record has so far proven to be useful in bringing alternative experiences to the production and use of grinding tools, as well as different social frameworks, values and ideas associated with this group of objects. Grinding tools of a variety of models have been manufactured and used by hunters and gatherers, horticulturalists and agriculturalists. Critical studies related to particular and contextual differences in tool design and tool use among cultural groups, is naturally of crucial importance. Unfortunately, aspects of women's everyday activities have received less attention than men's lives. As grinding tools and food-procuring activities are linked to the female sphere, they are consequently not as extensively documented by ethnographers (Bird 1993:23).

Contrary to the predominant interpretation of stone tool production as a strictly male activity, it is evident that grinding tools were used, produced and owned by women (Haaland 1978:57, 1995:164-166, 1997:378-379). Randi Haaland (1995:165) describes how every woman in the village of Dor in northwest Sudan has a private sandstone quarry of her own. There she collects the best raw material suited for grinding-tool production. She pecks the grinding-tool preform at the quarry and carries the roughly shaped preform back to the village. The final shaping of the grinding tool is done here. The manufactured and carefully kept grinding tools made by the women of Dor lasted for about three years (Haaland 1995:169). Ethnographic sources from the American south-west also describe grinding-tool manufacture as a female activity (Schlanger 1991:481).

\section{Grinding tools as expressing human relationship}

Among the Bemba tribe in Zambia the activity of grinding was a directly associated metaphor for ideas of marriage, as well as economic and social independence (Richards 1969). The mother of the bride decided when the bride was entitled to run a separate and self-supporting household unit. It was not unusual that the young family had to wait several years before it was fully accepted as a household by the community. During this time of transition the 
young woman was prohibited from storing grain and owning grinding equipment. The mother of the bride administered cereals and grinding tools (Richards 1969:125). The final cultural and economic transition to womanhood was therefore not only expressed by the act of marriage, or by having or raising children. The material symbolic expression of the identity of adult women was when married women were permitted to run a self-supporting household, when they could grind and store their own grain, and own a personal grinding tool.

Ceramic sculptures of domestic tools and activities, together with wall- and floor paintings, were explicitly used among the Bemba as social signifiers in the female initiation rites (Corbeil 1985:7). The ceremonies or rites de passage served as a guide to the social obligations and expectations of adult women. A senior woman performed the ceremonial rites. She presented the initiates with objects symbolising subsistence production. During the rite, the initiates were instructed in the use of the objects as well as in social and moral life and the role of adult womanhood. The symbols and paintings were accompanied by didactic singing and dancing based upon the aphorism, "I hear, I forget; I see, I remember. The eyes are better pupils than the ears" (Corbeil 1985:11). The song lyrics usually had ambiguous meanings.

One of the ceramic sculptures used in the ritual was named Napela, "the grinding woman" (Corbeil 1985:89). This functional symbol was used to express and explain how a married woman had to use her grinding tool. She must grind cereals into fine flour without damaging the tool, that is without creating too much friction between the handstone and the grinding slab. Gender complementarity and conceptions about the ideal relationship between man and woman, in conformity with accepted norms, were expressed metaphorically in the activity of grinding and symbolically by the grinding tool. In this way the young girl learned that she was responsible for creating a marriage without too much frictions.
Another domestic symbol used during the initiation rite was Kabende, a ceramic sculpture of a mortar and pestle (Corbeil 1985:88). The mortar was the material symbol of a woman, while the pestle represented a man. Together they became a metaphor of the ideal marriage and manifested the relationship of man and woman. The mortar symbol was used as a vital metaphor expressing similar values as the "grinding woman".

Ideas of grinding tools as expressing human relationships are also found among Zapotec Indian communities in Mexico. A set of grinding tools of high quality was used as a traditional wedding gift. The elaborately manufactured, loaf-shaped handstone was referred to as being the child. The relationship between the handstone and the grinding slab was a metaphorical expression of the close unit of mother and child (Parsons 1970).

Among hunter/gatherers, different activities associated with grinding tools are often bound up with female identity and female activities (Cane 1989:112). The grinding tool is the largest stone implement in the stone tool kit used by Australian Aboriginals. It was owned by women. The most elaborately produced grinding tool had a convex bottom, which was smoothed and finished by pecking (Mc Carthy 1941:332). The Aboriginal tribes usually did not carry their grinding tools with them when moving from site to site. Instead, they left the heavy grinding tools behind. To protect the grinding tools from wind and rain erosion they were placed upside down at a memorable spot at the old site, usually at the women's homebase camp (McCarthy 1941; Cane 1987:112; Thompson 1964:407). It seems clear that the grinding tools were deposited with the distinct intention of returning. This ethnographic information is therefore interesting when discussing human intentionality in relation to prehistoric mobility pattern.

\section{CONCEPTUAL CHANGES, GRINDING TOOLS AS RITUAL METAPHORS}

Conceptual changes connected with the wider 
economical, social, and ideological roles of grinding and pounding tools within prehistoric societies are, in fact, slowly developing in Sweden (e.g. Stjernquist 1987:149-157; Fendin 1994; Hagberg 1990:11-12; Hallgren 1996; Hallgren et al. In press 1997; Lidström Holmberg 1993; Kaliff 1997:88-90; Karsten 1994:98-100; Kihlstedt 1996:74-75; Olausson 1988:23-24, 28). The increasing interest in grinding-tool roles is mainly due to new and extraordinary finds.

Alasdair Whittle (1996) implies that the idea of transformation and regeneration was a ritualised structure in Early and Middle Neolithic Europe. This structure was reproduced in the material culture by people's actions. Elaborately manufactured grinding tools are in the same way linked to changes in Neolithic life styles among early European farmers (Henning 1966; Hodder 1990). Similarities in artefactual remains between communities belonging to Linear Bandkeramik Cultures and communities in southern Scandinavia have long suggested ties in the Mesolithic Neolithic period (Fischer 1982; Jennbert 1984; Whittle 1996). It is therefore interesting to note the similarities in tool design between LBK grinding tools and the saddle-shaped grinding tools found in various Early Neolithic contexts in middle Sweden.

Hodder (1990) has proposed a structuralistic model based upon binary oppositions, where domestication of society is achieved through an ideology of the domestication (female domus) of the wild (male agrios). The term "domus" represents a concept involving a domestic symbolism focused on fertility and social reproduction. The domus includes women, children, domestic production, storage, and ritualised activities centred round the hearth as the focal point of the house. Grinding tools, storage vessels, and clay figurines are all associated with the female domus. The concept of agrios is associated with the wild, men, warring, prestige, exchange, hunting, domestic animals, and death. Weapons, axes, and stone tool production are part of the male agrios (Hodder 1990:69:fig. 3.5, 83-84).
Grinding tools are interpreted as things with symbolic transformatory qualities (Hodder 1990:68). Although grinding tools are discussed as social objects, it is also clear that the model includes many conventional and simplistic assumptions about, for example gender relationships (see e.g. Whittle 1996:8).

Jonathan Last (1996:38) discusses how the symbolic character of the Neolithic domestic structure is made manifest by the various ways that grinding tools were deposited, for example in dug pits. He suggests that the deposition of grinding tools may be interpreted as a metaphor related to fertility and reproduction. Like Hodder (1990), he stresses the role of the house in the process of social reproduction.

An increasing number of Neolithic fenced and ditched enclosures have been found in Europe and southern Scandinavia (Andersen 1997). The enclosures may be interpreted as having an integrating role as local arenas for the embodiment of wider ideas, defining a sense of identity and celebrating domesticity (Whittle 1996:274). Artefact assemblages found in pits within the enclosed areas, as well as from the system-ditches of the Sarup enclosures, not only include pottery, flint and stone artefacts, animal and human bones, and carbonized grain, but also grinding tools (Andersen 1997:54:fig.60, 62, 85, 111, 122). Deliberately placed grinding tools are also frequently found at other Neolithic enclosed structures in Europe (Andersen 1997: e.g. 200, 226, 229). It appears that some of these material finds are result of deliberate deposition, sometimes associated with the intentional destruction or breakage of objects (Andersen 1997; Whittle 1996:272-273).

Grinding tools found in a variety of Neolithic contexts in Sweden strengthen ritual interpretations of grinding tools, for example as burial or sacrificial offerings ( $\mathrm{t}$ ex Kihlstedt 1996; Malmer 1962:572), or as votive offerings in wetlands (Hagberg 1990:11-12; Hallgren et al. 1995b: In press; Stjernquist 1987). The archaeological finds of grinding and pounding tools complicate a single func- 
tional and profane model of interpretation. Functional artefacts are obviously involved in value-laden contexts that may be interpreted as having ceremonial and ritual character (Karsten 1994:99).

Saddle-shaped grinding tools are, as earlier described, products of elaborate design. Sometimes they are far more elaborate than their practical function calls for. This is particularly demonstrated by some exclusive loaf-shaped handstones of considerable length found at the Early Neolithic Funnelbeaker (TRB) inland site of Skogsmossen, Fellingsbro parish in Västmanland (Hallgren et al. 1995b). The remarkable elongated handstones, made of micaceous schist, may be interpreted as having symbolic properties. They were deposited in a straight line across the southern part of a small fen, situated close to a farmstead (fig. 6). The fen revealed large amounts of Early Neolithic finds, of which some had been objects of deliberate destruction. The fen has been interpreted as a votive offering fen (Hallgren et al. In press. 1997).

Archaeological data also suggest a ritual practice involving the deliberate deposition of grinding tools inside rituals pits. This is further support for discussing grinding tools as metaphorical traces of the past. The ritual practice connected with grinding tools seems to have been present both in Europe and in Sweden in the Early and Middle Neolithic (Hodder 1990; Last 1996; Karsten 1994; Whittle 1996).

A similar practice may have been present in the Mesolithic - Neolithic transition in middle Sweden. Pärlängsberget is a late Mesolithic settlement site (c. 4000 cal. BC) in Överjärna parish, Södermanland (Hallgren $e t$ al. 1995a). During the Mesolithic - Neolithic transition the site was shore-bound. The finds from the site consist mainly of knapped quartz

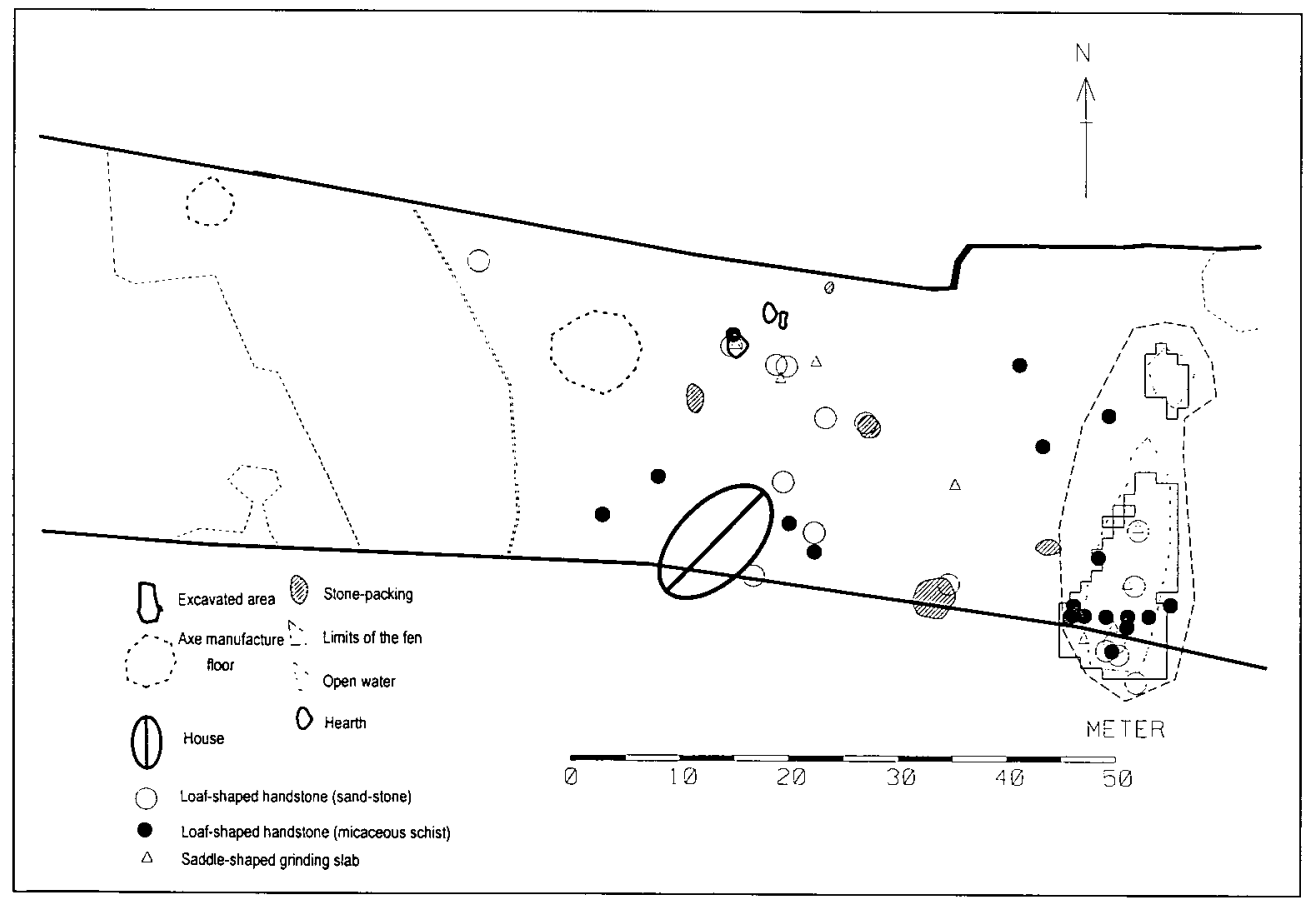

Fig. 6. The distribution of grinding-tool parts at the Early Neolithic Skogsmossen site, Fellingsbro parish, in Västmanland. Four intact and fragmentary saddle-shaped grinding slabs, and 18 loaf-shaped handstones were found in the southern part of the offering fen. Note the remarkable deposition of loafshaped handstones in a straight line across the fen. After Hallgren et al. 19956. 


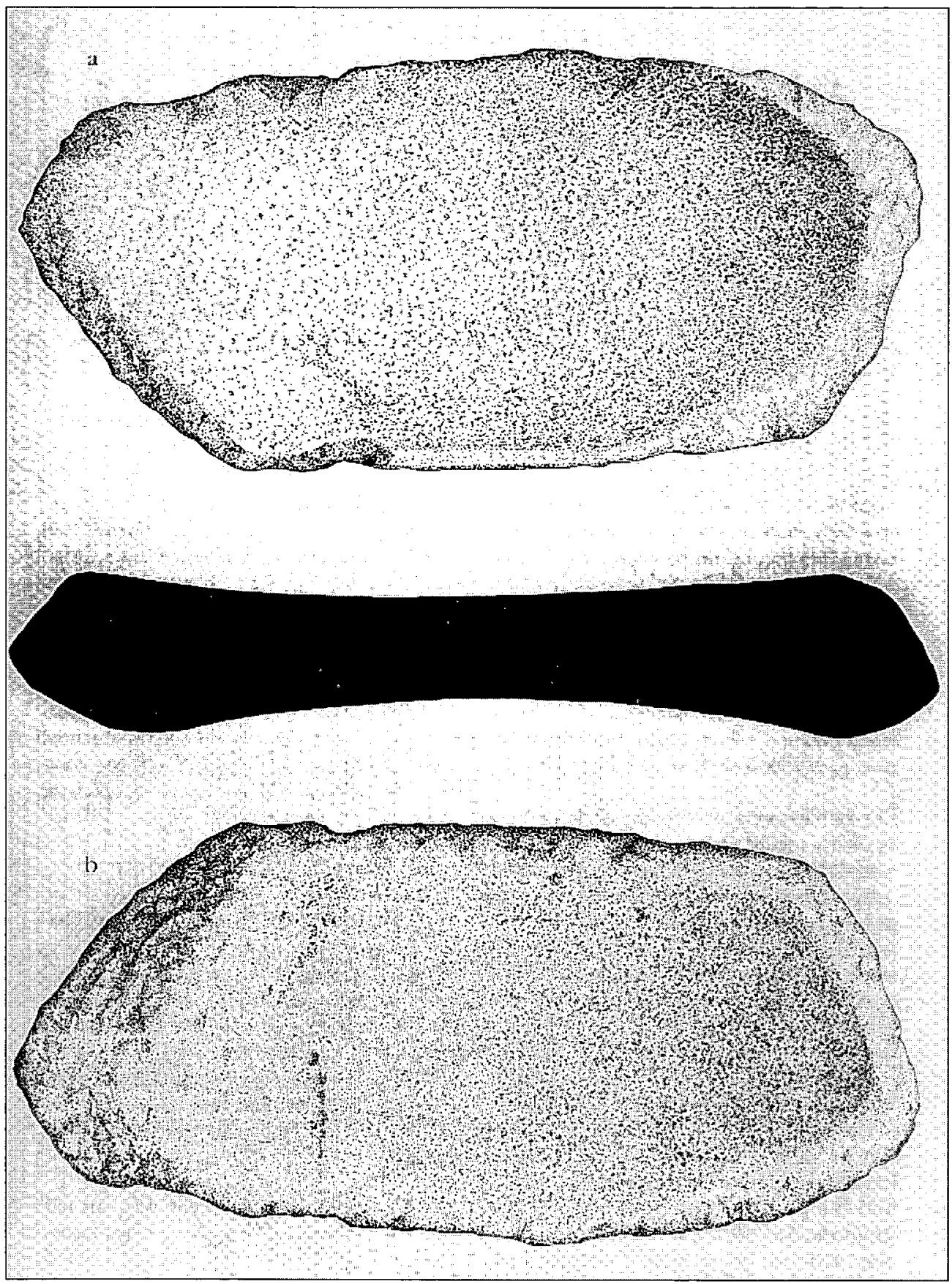

Fig. 7. The saddle-shaped grinding slab from the Late Mesolithic settlement site of Pärlängsberget, Överjärna parish, in Södermanland. The slab was found deposited in an upright position. The back of the grinding slab has been used for polishing stone tools. Note the difference in use-wear between the rugged grinding surface (a), and the smooth, striated polishing surface (b). Drawing: Mikael Söderblom. After Hallgren et al. 1995 . 
and small quantities of knapped greenstone, the latter debris from axe production. In one of the excavated huts a small saddle-shaped grinding slab (fig. 7) was found deposited in an upright position at the edge of a hearth (Hallgren et al. 1995a:19, 21). A similar deposition with a grinding slab in an upright position was also found at Skogsmossen (Hallgren 1996:9). One explanation is that the grinding tool was discarded and that the pit is a refuse pit. The deliberate nature of the finds may, however, suggest an intentional depositing of domestic objects such as described from LBK-sites in Europe. The act of offering often includes hiding or discarding (Renfrew \& Bahn 1991:360). The burial of discarded sacred or ritual objects is a ritual institution or a regular pattern of behaviour in every religious community (Garfinkel 1994).

The fact that grinding tools seem to be involved in intentional acts of deposition is of importance for a re-valuing of grinding tools as objects of respect and multiple meaning. Berta Stjernquist (1987:155-156) proposes that cultic activities involving functional objects, such as grinding tools, are part of a long-lived cult tradition lasting from the introduction of agricultural ideas until the Roman Iron Age. This cult is proposed to have been intimately bound up with conceptions of daily life of people, their economic ambitions, and the desire for continued fertility. Stjernquist suggests that the use of the products of economy in the cult should be interpreted as directly linked to the functional and economic value of the objects.

The symbolic significance of grinding tools as metaphors is explicitly expressed by the two large and partly stone filled pits which were excavated in 1994 at the Östra Vră site, Stora Malms parish, in Södermanland (Kihlstedt 1996:74-75). The pits were c. 2 x 4 meters in diameter and contained charred bones and teeth from children. One of the pits also contained carbonised seeds of cereals (Triticum), of which one has been radiocarbon dated to $3500-3100 \mathrm{cal}$. BC. The stonepacking covering each pit was made up of an astonishly large number of intact or fragmented grinding tools, about 80 all in all. The majority of tools consist of carefully manufactured saddleshaped grinding slabs, made of arcosic sandstone and granite. They show different stages of use-wear, but most seem to have been fully functional when deposited. It cannot be excluded that some of the grinding slabs may have been produced for this particular deposition activity. A few grinding slabs can be considered as worn-out and discarded, at least in the functional sense. Some grinding slabs had been broken before deposition. This may suggest that they have been involved in a practice that included intentional destruction, or the ritual killing of objects. The interpretation of the grinding tools as selected and intentionally deposited objects, points toward a ritual act with domestic tools as sacrificial gifts. They might also be remains of a sacrificial drama or act, perhaps performed for a specific purpose (Karsten 1994:25-26).

One of the many questions raised by the grinding tools found at Östra Vrå is why so many grinding tools were deposited, especially since TRB-economy is considered to have been based on pastoralism rather than cereal cultivation (Lidén 1995). Ethnographic observations, for example among traditional agriculturists in Sudan, show that every household owned at least one grinding tool, but usually two (Haaland 1978:57). In light of this information, the abundance of grinding tools found at Östra Vrå is remarkable. It can be suggested that the act of deposition at Östra Vrå involved participation by more than one household. The deposited grinding tools may represent several different households, joined together in the ritual act. The abundance of grinding tools can have served as a joining metaphor, manifesting and creating a sense of identity among members of a community, or perhaps with the aim of integrating separate communities (see Whittle 1996:274).

Analyses of microfossil remains have proven to be useful as a complement in archaeological interpretations related to tool function (Pearsell 1989; Risberg et al. ms). 
Identified microfossil remains left on the grinding surfaces of two of the grinding slabs from Östra Vră, one from each pit, resulted in two different sets of microfossils (Risberg et al. ms). This may be an indication that the grinding slabs emanated from different sources, and were in fact brought to the ritual act by the participants.

\section{CONCLUSIONS}

Critical analysis of theoretical concepts such as mundane-ritual, functional-symbolical, gender, and value-systems have opened up new possibilities of discussing grinding tools as something beyond the functional. Grinding tools have been found in a wide variety of

\section{REFERENCES}

Adams, J. 1988. Use-wear Analyses on Manos and Hide-Processing Stones. Journal of Field Archaeology 15. Pp. 307-315.

Andersen, N. H. 1997. The Sarup Enclosures. The Funnel Beaker Culture of the Sarup site including two causewayed camps compared to the contemporary settlements in the area and other European enclosures. Sarup vol. I. Jutland Archaeological Society Publications XXXIII: 1. Jysk Arkæologisk Selskab. Moesgaard.

Apel, J. E. (Ed). In press. Skumparberget 1 och 2. En mesolitisk aktivitetsyta och tidigneolitiska trattbägarlokaler vid Skumparberget $i$ Glanshammarsn, Örebro län, Närke. Arkeologikonsult, Upplands Väsby.

Ballin, T.B. 1996. Klassifikationssystem for stenartefakter. Varia 36. Universitetets Oldsakssamling. Oslo.

Barker, G. 1985. Prehistoric farming in Europe. New Studies in Archaeology. Cambridge University Press. Cambridge.

Bauche, R-D. 1986. Gebrauchsspuren an neolitischen mahlsteinen. Archäologische Informationen 11 (2). Bonn.

Bennet, R. \& Elton, J. 1898. "Handstone, slave and cattle 'mills'". History of corn milling, vol 1 . London.

Bird, C. F. M. 1993. Woman the toolmaker: evidence for women's use and manufacture of flaked stone tools in Australia and New Guinea. In: du Cros, H. \& Smith, L. (Eds). Women in Archaeology. A Feminist Critique. Pp. 22-30.
Neolithic contexts. A change in attitude, related to new extraordinary finds, can be said to have rendered grinding tools new and positive archaeological value.

It has been argued that saddle-shaped Neolithic grinding tools should be seen as intentional products, belonging to the wider social and symbolical world of the Neolithic. A symbolic order associating grinding and grinding tools with death, transformation and transition, as well as human relationships, identity, and social and economic reproduction, may well have been present in the Neolithic.

English revised by Laura Wrang.
Occasional Papers in Prehistory, No. 23. Department of Prehistory. The Australian National University, Canberra.

Cane, S. 1989. Australian aboriginal seed grinding and its archaeological record: a case study from the western desert. In: Harris, D. R. \& Hillman, G. C. (Eds). Foraging and Farming, the Evolution of Plant Exploitation. One world archaeology 13. London.

Carter, G. F. 1977. The metate: an early graingrinding implement in the New World. In: Reed, C. A. (Ed). Origins of Agriculture. Pp. 693-712. Mouton publishers. The Hague.

Conkey, M.W. 1993. Making the connections: feminist theory and archaeologies of gender. In: du Cros, H. \& Smith, L. (Eds). Women in Archaeology. A Feminist Critique. Pp. 3-15. Occasional Papers in Prehistory, No. 23. Department of Prehistory. The Australian National University, Canberra. Australia.

Corbeil, J. J. 1985. Sacred emblems of the Bemba. Ethnographic Arts \& Culture Series 4. London.

Damm, C. B. 1991. Continuity and Change. An analysis of social and material patterns in the Danish Neolithic. Ph.D. Thesis, Department of Archaeology, University of Cambridge.

Dobres, A-M. 1995a. Beyond gender attribution: Some methodological issues for engendering the past. In: Balme, J. \& Beck, W. (Eds). Gendered Archaeology. The second Australian Women in Archaeology Conference. Research Papers in Archaeology and Natural History No 
26. Australian National University.

- 1995b. Gender and prehistoric technology: on the social agency of technical strategies. World Archaeology; vol 27 (1). Pp. 25-49.

Ek, S.B. 1981. "Kvarn \& Kvarnrätt". Kulturhistorisk leksikon for Nordisk Middelalder. 2 oplag. Band 9. Pp. 536-550, 553-554.

Engelstad, E. 1991. The symbolism of everyday life in prehistory. In: Baudou, E. (Ed). Nordic TAG. Report from the 2: nd Nordic TAG conference. Archaeology and Environment 11. Pp. 23-32. Umeå.

Fendin, T. 1994. Att vara närvarande i bildenmalning och identitet. Seminar paper. Institute of Archaeology, University of Lund.

Fischer, A. 1982. Trade in Danubian shaft-hole axes and the introduction of Neolithic economy in Denmark. Journal of Danish Archaeology 1. Pp 7-12.

Florin, S. 1958. Vråkulturen. Stenåldersboplatserna vid Mogetorp, Östra Vrå och Brokvarn. Stockholm.

Garfinkel, Y. 1994. Ritual Burial of Cultic Objects: The Earliest Evidence. Cambridge Archaeological Journal 4:2. Pp. 159-188. Cambridge.

Gero, J. \& Conkey, M. (Eds). 1991. Engendering Archaeology: Women and Prehistory. Oxford.

Haaland, R. 1978. Ethnographical Observations of Pottery-Making in Darfur, Western Sudan, with some Reflections on Archaeological Interpretation. In: Kristiansen, K. \& Paludan-Müller, C. (Eds). New Directions in Scandinavian Archaeology. Studies in Scandinavian Prehistory and Early History, vol. 1. The National Museum of Denmark.

- 1995. Sedentism, Cultivation, and Plant Domestication in the Holocene Middle Nile Region. Journal of Field Archaeology 22:2. Pp. 157174. Boston University. Boston.

- 1997. Emergence of sedentism: new ways of living, new ways of symbolizing. Antiquity, vol 71. Pp. 374-385.

Hagberg, U. 1990. Mitt i offermossen stod en skulpterad påle. Populär Arkeologi 1990, nr 2. Pp. 11-12. Lund.

Hallgren, F. 1996. Sociala territorier och exogamirelationer i senmesolitisk tid. En diskussion utifrån boplatsen Pärlängsberget, Södermanland. TOR, vol. 28. Pp. 5-27. Uppsala.

Hallgren, F. et al.1995a. Pärlängsberget, en kustboplats från övergången mellan senmesolitikum och tidigneolitikum. Tryckta rapporter från Arkeologikonsult AB 13. Upplands Väsby.

- 1995b. Ms. Skogsmossen, en tidigneolitisk booch offerplats $i$ norra Mellansverige. Slutundersökningsrapport, RAÄ 633, Fellingsbro sn, Västmanland, Örebro län. Arkeologikon- sult AB. Upplands Väsby.

- In press. 1997. Skogsmossen, an Early Neolithic settlement site and offering fen, in the northern borderland of the Funnel-beaker Culture. TOR, vol. 29. Uppsala.

Hard, R. J., Mauldin, R. P. \& Raymond, G. R. 1996. Mano Size, Stable Isotope Ratios, and Macrobotanical Remains as Multible Lines of Evidence of Maize Dependence in the American Southwest. Journal of Archaeological Method and Theory 3, No 4. Pp. 253-318. New York.

Hastorf, C. A. 1991. Gender, Space, and Food in Prehistory. In: Gero, J. M. \& Conkey, M. W. (Eds). Engendering Archaeology. Pp. 132-159. Oxford/Cambridge.

Henning, E. 1966. Beobachtungen zum mahlvorgang an ur- und frühgeschichtlichen getreidemühlen. Etnographish-Archäologische Forschungen, 7. Berlin Deutscher.

Hermelin, E. M. 1912. Knackstenar och deras användning. Fornvännen. Pp. 67-71. Stockholm.

Hersch, L. T. 1981. Grinding Stones and Food Processing Techniques of the Neolithic Societies of Turkey and Greece: Statistical, Experimental and Ethnographic Approaches to Archaeological Problem-solving. Ph. D. dissertation, Colombia University, New York. University Microfilms, Ann Arbor.

Hodder, I. 1990. The Domestication of Europe. Oxford.

Hole, F. et al. 1977. Studies in the Archaeological History of the Deh Luran Plain. The Excavation of Chagha Sefid. Memoirs of the museum of anthropology, University of Michigan, No 9. Ann Arbor.

Hugh-Jones, 1996. Houses in the Neolithic imagination: an Amazonian example. In: Darvill, T. \& Thomas, J. (Eds). Neolithic Houses in Northwest Europe and Beyond. Oxford.

Jennbert, K. 1984. Den produktiva gåvan. Tradition och innovation $i$ Sydskandinavien för omkring 5300 år sedan. Acta Archaeologica Lundensia, Series in $4^{\circ}, N^{\circ} 16$. Lund.

Jørgensen, B.A. 1991. Jernalderdrejkværne - form og funktion. In: Eksperimentel Arkcoologi, studier $i$ teknologi og kultur, $\mathrm{nr}$ 1/1991. Historisk-Arkæologisk Fors $\emptyset$ gscenter, Lejre.

Kaliff, A. 1997. Grav och Kultplats. Eskatologiska föreställningar under yngre bronsålder och äldre järnålderi Östergötland. Aun 24. Uppsala.

Karsten, P. 1994. Att kasta yxan i sjön: en studie över rituell tradition och förändring utifrån skånska neolitiska offerfynd. Lund.

Kihlstedt, B. 1996. Neolitiseringen i Östra Mellansverige - några reflektioner med utgångspunkt från nya 14C-dateringar. In: Bratt, P. (Ed). Stenålder i Stockholms län. Pp. 72-76. Stock- 
holms Länsmuseum.

Kraybill, N. 1977. Pre-agricultural tools for the preparation of foods in the Old World. In: Reed, C. A. (Ed). Origins of Agriculture. Pp. 485521. Mouton publishers. The Hague.

Last, J. 1996. Neolithic houses - a central European perspective. In: Darvill, T. \& Thomas, J. (Eds). Neolithic Houses in Northwest Europe and Beyond. Oxford.

Lidén, K. 1995. Prehistoric Diet Transitions: An Archaeological perspective. Theses and papers in scientific archaeology 1. Stockholm Archaeological Research Laboratory. Stockholm.

Lidström Holmberg, C. 1993. Sadelformade malstenar från yngre stenålder. "Grind my dear one, let her grind". Unpublished report. Flaten projektet, Rapport 2. Statens historiska museum, Stockholm/Inst. för Arkeologi, Uppsala universitet.

Lübcke, P. (Ed). 1988. Diskurs. In: Filosofilexikonet. P. 117. Bokförlaget Forum. Stockholm.

Malmer, M. P. 1962. Jungneolithische Studien. Acta Archaeologica Lundensia. Series in $8^{\circ}$. No 2. Lund.

Mc Carthy, F. D. 1941. Aboriginal Grindstones and Mortars. Australian Museum Magazine 7. Pp. 329-333.

Moore, L. H. 1986. Space, Text and Gender: An Anthropological Study of the Marakwet of Kenya. Cambridge University Press. Cambridge.

- 1991. Epilogue. In: Gero, J. \& Conkey, M. (Eds). Engendering Archaeology: Women and Prehistory. Pp. 407-411. Oxford.

Müller, S. 1907. Nye fund og iakttagelser fra sten-, bronze- og jernalderen. Aarbøger for nordisk Oldkyndighet. København.

Nelson, M. C. \& Lippmeier, H. 1993. Grindingtool design as conditioned by land-use pattern. American Antiquity, 58 (2). Pp. 286-305.

Olausson, M. 1988. Ett gravfält frain romersk järnålder vid Ådalen i Angarnsjöområdet. Raä 68, Hacksta, Össebygarns sn. Uppland. Arkeologiska Rapporter och Meddelanden från Institutionen för Arkeologi vid Stockholms Universitet, $\mathrm{Nr} 20$. Stockholm.

Olsson, E. 1992. The Grödinge investigations - an example of interdisciplinary study and collaboration. In: Laborativ Arkeologi 6. Pp. 31-36. The Archaeological Research Laboratory. Stockholm University.

- 1996. Neolitikum i Stockholms län-källmaterial och forskningsläge. In: Bratt, P. (Ed). Stenålder iStockholms län. Pp. 40-65. Stockholms Länsmuseum.

Parsons, E. 1970. Mitla, Town of the Souls. Chicago University press.
Pearsell, M. D. 1989. Paleoetnobotany. A handbook of procedures. Academic press. San Diego.

Petré, B. 1984. Arkeologiska undersökningar på Lovö. Del l. Neolitikum, bronsålder och äldsta järnålder. Acta Universitatis Stockholmiensis. Studies in North-European Archaeology 7. Stockholm.

Renfrew, C \& Bahn, P. 1991. Archaeology: Theories, Methods and Practice. London.

Richards, A. I. 1969. Land, Labour and Diet in Northem Rhodesia: An Economic Study of the Bemba Tribe. London.

Risberg, J. et al. Ms. Siliceous microfossils, especially phytoliths, as recorded in five prehistoric sites in eastern middle Sweden.

Roberts, C. 1991. A critical approach to gender as a category of analysis in archaeology. In: du Cros, H. \& Smith, L. (Eds). Women in Archaeology: A Feminist Critique. Occasional Papers in Prehistory, No 23. Department of Prehistory. The Australian National University. Canberra.

Rydbeck, O. 1912. Undersökning av bronsåldershögar i Köpinge nära Ramlösa hälsobrunn i Skåne. Fornvämnen. Pp. 81-132. Stockholm.

Schlanger, S. H. 1991. On manos, metates, and the history of site occupations. American Antiquity 56 (3). Pp. 460-474.

Schön, V. 1995. Die Mühlsteine von Haithabu und Schleswig. Ein Beitrag zur Entwicklungsgeschichte des mittelalterlichen Mühlenwesens in Nordwesteuropa. Berichte über die Ausgrabungen in Haithabu. Bericht 31. Wachholtz Verlag. Neumünster.

Schön, W. \& Holter, U. 1988. Zum gebrauch von reib- und mahlsteinen in der Ostsahara. Archäologische Informationen /1 (2). Bonn.

Sharovskaja, T. A. 1992. Mala på kopior av tidiga kvarnstenar. Forntida teknik 2/92. Sveg.

Stjernquist, B. 1987. Spring-cults in Scandinavian Prehistory. In: Linders, T. \& Nordquist, G. (Eds). Gifts to the Gods. Proceedings of the Uppsala Symposium 1985. Boreas. Uppsala Studies in Ancient Mediterranean and Near Eastern Civilizations 15. Pp. 149-157. Uppsala.

Stone, T. 1994. The impact of raw-material scarcity on ground-stone manufacture and use: An example from the Phoenix Basin Hohokam. American Antiquity 59. Pp. 680-694.

Sørensen, M. L. S. 1988. Is there a feminist contribution to archaeology? Archaeological Review from Cambridge, vol. 7:1. Pp.9-20. Cambridge.

Thomas, J. 1991. Rethinking the Neolithic. New Studies in Archaeology. Cambridge University Press.

Van de Velde, P. 1992. Dust and ashes: the two Neolithic cemeteries of Elsloo and Niedermerz compared. In: Bakels, C. (Ed). The End of Our 
Third Decade. Papers written on the occasion of the 30th anniversary of the Institute of Prehistory, vol.1. Analecta Praehistorica Leidensia. University of Leiden.

Welinder, S. 1977. The Mesolithic Stone Age of Eastern Middle Sweden. Antikvariskt arkiv 65. Stockholm.

Whittle, A. 1996. Europe in the Neolithic. The creation of new worlds. Cambridge University Press.
Wright, K. I. 1990. Sandstone and Cornmeal: Experimental Use of Early Pueblo Maize Grinding Tools from Southwestern Colorado. Unpublished Master's thesis, Department of Anthropology, Washington State University, Pullman.

Wylie, A. 1982. Epistemological Issues Raised by a Structuralist Archaeology. In: Hodder, I. (Ed). Symbolic and Structural Archaeology. Pp. 3946. Cambridge University Press, Cambridge. 